\title{
Sexual dimorphism and pore systems in Ordovician ostracodes
}

\author{
Roger E.L. Schallreuter and Ingelore C.U. Hinz-Schallreuter \\ Acta Palaeontologica Polonica 55 (4), 2010: 741-760 doi: http://dx.doi.org/10.4202/app.2009.0056
}

Open antra, a special form of external brood pouches in Ordovician ostracodes suitable for both egg and brood care, are enabled by the associated pore system. Special kinds of radial pores connected with the adventral sculptures are described for the first time. Relationships exist between antral development and lifestyle in that open antra occur in nektobenthic taxa, while closed antra (false brood pouches) are connected with a benthic lifestyle. Taxa, particularly those with open antra, which are morphologically very similar in being non-lobate or non-sulcate, can be distinguished by the construction of the respective antra and the associated pore systems, as exemplified by Levisulculus, Swantina, and Ampletochitina.

Key words: Arthropoda, Crustacea, Ostracoda, Levisulculus, Swantina, Ampletochilina, erratic boulders, dimorphism, adventral radial pores, Ordovician, Baltoscandia.

Roger Schallreuter [Roger.Schallreuter@uni-greifswald.de], Ingelore Hinz-Schallreuter [ihinz-s@uni-greifswald.de], Institute of Geography and Geology, Ernst Moritz Arndt University, Friedrich Ludwig Jahn str. 17a, D 17489 Greifswald, Germany.

This is an open-access article distributed under the terms of the Creative Commons Attribution License (for details please see creativecommons.org), which permits unrestricted use, distribution, and reproduction in any medium, provided the original author and source are credited. 